\title{
SELECTION FOR CADMIUM-TOLERANCE IN BIOMPHALARIA ALEXAN- DRINA SNAILS CHARACTARIZATION BASED ON GENETIC STUDIES, AND SUSCEPTIBILITY TO SCHISTOSOMA MANSONI ASSOCIATION
}

\author{
By \\ SHADIA H. MOHAMED ${ }^{1}$, HANAA M. M. EL KHAYAT ${ }^{2}$, SAMIA M. FAWZI ${ }^{1}$ \\ AND DINA G. TAWFIK ${ }^{\star}$
}

Department of Zoology ${ }^{1}$, Faculty of Science, Ain Shams University, Cairo 11566, and Environmental Research Laboratory ${ }^{2}$, Theodor Bilharz Research Institute, Embaba P.O. Box 30, Giza, Egypt ( ${ }^{*}$ Correspondence: dina-Gamall@hotmail.com)

\section{Abstract}

Biomphalaria alexandrina snails were examined for their tolerance to cadmium $(\mathrm{Cd})$ toxicity through three generations produced by self-fertilization by exposing snails to serial concentrations of $\mathrm{Cd}$ and selection for the most tolerant ones through the successive generations. Results showed a gradual increase in the $\mathrm{LC}_{50} \& \mathrm{LC}_{90}$ values via successive generations indicating tolerance upgrading phenotype. Also, the selected and non-selected snails were examined for susceptibility to Schistosoma mansoni and hematological criteria. B. alexandrina showed refractory tendency with significant increase in hemocytes; granulocytes; indicating that defense mechanism was stronger than other ones. The dendro-gram based on the similarity matrices of ISSR-PCR banding patterns resulted with ten random primers, showed that the selected groups of the $1^{\text {st }}$ and $2^{\text {nd }}$ generations were the most similar and clustered together forming a distinct group that in turn cluster with nonselected laboratory group that in turn cluster with parent group (field, non-selected), while the $3^{\text {rd }}$ selected generation was the most divergent group, indicating its genetic drift. The mating system and selection succeeded in evolution of $\mathrm{Cd}$ tolerance snail isolate; characterized genetically, physiologically, showed refractory tendency to S. mansoni infection.

Keywords: Biomphalaria alexandrina, toxicity curve, cadmium-tolerance, genetic selection, hemocytes, Schistosoma mansoni, infection, ISSR, similarity, dendrogram.

\section{Introduction}

Generally, molluscs play a role in the balance of nature, and also act as biological indicator, in determining the degree of pollution of water and terrestrial environment. The genus Biomphalaria was intensely studied due to its relation to the schistosomiasis (Barbosa and Coimbra, 1979). Moreover, Biomphalaria has been used for more than 30 years for toxicological studies and as a bio-indicator for environmental monitoring studies. Many aspects make this genus a good model for laboratory studies; has a wide geographical distribution, low dispersion and is easily collected, easy to breed, need little space, can reproduce throughout the year under controlled conditions and have a short life-span (Tallarico et al, 2012). Heavy metals are common environmental pollutants to the aquatic organisms. Several studies have documental that Biomphalaria exposed to $\mathrm{Cd}$ continued to be reproductively active and no significant effect of heavy metal exposure was demonstrated (Abd Allah et al, 1997). This tolerance to acute metal levels may result from genetic selection (genotypic) which might be expressed phenotypically; or through an adjustment of biochemical or physiological mechanisms (phenotypic) without a genetic basis (Lam, 1996). Irrespective of the basis, mechanisms of metal tolerance in aquatic invertebrates may involve in reducing uptake or increasing excretion, leading to low accumulation (Bryan and Gibbs, 1983) or storage in inert forms, which may be coupled with enhancing uptake (Brown, 1978 and Depledge and Rainbow, 1990).

As a consequence of studies by Richards and Merritt, 1972; Richards 1973, 1977; 1984; El-Khayat et al. (2005) and Saber et $a l$. (2007) it was concluded that the susceptibility of Biomphalaria species to Schistosoma mansoni infection is a inheritable trait that genetically controlled. Characterizing of host and parasite population genetic struc- 
ture and estimating gene flow among populations depending on allozyme analysis and molecular tools was essential to understand co-evolutionary interactions between host and parasites (Jrane and Theron, 2001; Charbonnel et al, 2002; Prugnolle et al, 2005; ElKhayat et al, 2007; Wethington and Lydeard, 2007; Mohamed et al, 2012; Standley et al, 2014).

The snail immune-biology is strongly related to the circulating cells in the hemolymph or hemocytes and to humoral factors within the snail plasma (Lie, 1982; Loker and Bayne, 1986; Van der Knaap and Loker, 1990). Two main types of hemocytes are found in the Biomphalaria hemolymph: the granulocytes and the hayalinocyte. Some authors suggest that the hayalinocyte and the granulocytes are distinct cell types, while others consider that they represent different developmental phases of the same cell type. Seasonal factors and diverse physiological experimental conditions affect the total number, type and behavior of the hemocytes and the capacity of mollusks to respond strongly to stimuli depends on hemocytes viability and functional capacity (Oliver and Fisher, 1995). In this way, the number of hemocytes may vary according to certain stimuli, such as responses to infection by trematodes (Sullivan et al, 1984). Oliveira et al. (2010) recorded a differential behavior of defense cells that may be related to the resistant or susceptible phenotype, significant change of the number of granulocytes, while no statistically significant differences for the hayalinocyte. Kambale and Potdar (2010) found that the number of granulocytes was more in freshwater snail Bellamya bengalensis than the bivalve Lamellidens marginalis, which indicates that their humeral defense mechanism was stronger. Wright et al. (2017) succeeded for the first to identify and characterize an $\mathrm{H}^{+}$channel in B. glabrata hemocytes that may function in immune defense responses against larval $S$. mansoni.

Several studies (Newton, 1963; Sullivan et al, 1984; Jelnes, 1987; Yasuraoka et al, 1987; Saber et al, 2005; 2007, El-Khayat and Gawish, 2006; El-Khayat et al, 2005; 2008) isolated different snail lines at laboratory scales by self-fertilization and selections through many generations for certain characters susceptibility to infection, tolerance to chemical or plant molluscicides and different mantle pigmentation. These authors determined genetic alterations in these selected snail isolated by several techniques, enzymatic, protein and molecular. Inter simple sequence repeat polymerase chain reaction (ISSR)-PCR technique was used as simple sequence repeats anchored at the 5 or 3 'end by a short arbitrary sequence as PCR primers (Zitkiewicz et al, 1994). It was considered as a powerful tool for genetic mapping and assessment of genetic diversity between closely related species and also to detect similarities between and within species as well (Moreno et al, 1998; Ghariani et al, 2003; Szenejko et al, 2016). Also, The ISSR technique has been reported as a good marker to differentiate between geographically different Lymnaea natalensis populations and a laboratory isolate (El-Khayat et al, 2015).

The present study investigated Biomphalaria alexandrina for their tolerance to cadmium (Cd) toxicity by exposing snails to serial concentrations of $\mathrm{Cd}$ and selection for the most tolerant ones through successive generations in a trial to isolate $\mathrm{Cd}$ tolerant snail line. Selected tolerant and non-selected progenies were tested and compared for their susceptibility to $S$. mansoni infection, hematological analysis through total and differential hemocytes count and by molecular analysis through similarity matrices based on PCR-ISSR markers.

\section{Material and Methods}

Chemicals: Cadmium chloride: were supplied by Sigma-Aldrich, United Kingdom.

Snail samples: B. alexandrina, the interme diate host of Schistosoma mansoni were collected from irrigation canals in Giza Governorate, thoroughly washed and maintained 
under laboratory conditions in plastic aquaria, fed on green lettuce leaves for 4 weeks before being used as parent. During this period snails were examined weekly for their natural schistosome infection by exposure to a light source for an hour to detect any cercarial shedding.

Maintenance of snails: Adult parental snails were selected as healthy negative for natural infection of uniform size of 10-12 $\mathrm{mm}$. Each 50 snails were maintained in plastic aquaria containing 5 liters of dechlorinated tap water, which was changed weekly and snails were fed on boiled lettuce twice a week.

Estimation of cadmium (Cd) toxicity: Serial concentrations of $\mathrm{Cd}(0.5,2,4,6,8, \& 12$ $\mathrm{ppm} /$ liter in glass beakers) were done in 3 replicates and 10snails/replicate was added.

Another set with three replicates was done using dechlorinated tap-water only as a control. Exposure and recovery periods were 24 hours each and mortality counts were recorded and corrected according to (Abbott, 1925). Mortality regression lines were established by SPSS Computer Program 20.0.

Tolerant snail selection: All survivors in the $\mathrm{Cd}$ concentration $>4 \mathrm{ppm}$ were maintained individually to produce the next generation by self-fertilization, in plastic aquaria; each containing 5 liters of de-chlorinated tap water. Egg clutches were allowed to be hatched and the newly hatched snails reared in the same aquaria with their parents. Snails were fed on boiled lettuce twice a week, water has been changed monthly but release of departs and complete the water volume was done weekly. Adult $1^{\text {st }}$ generation snails from tolerant parents were tested for their $\mathrm{Cd}$ tolerance and selection and isolation for the most tolerant snails was done like their parents to produce the second generation that in turn produced the third generation with the same manner. For each $\mathrm{Cd}$ exposure toxicity test starting from the first generation, another test was done using negative mature field B. alexandrina of 10-12 $\mathrm{mm}$ size at the same time and conditions.
Mortality regression lines were established by SPSS Computer Program and used as a control.

Susceptibility to Schistosoma mansoni infection: Two groups the selected $B$. alexandrina of the $3^{\text {rd }}$ generation and lab breeding snails (as control) of the same size $5-7 \mathrm{~mm}$ were examined for susceptibility to $S$. mansoni infection. Each group was exposed individually to 7-10 freshly hatched $S$. mansoni miracidia that supplied by Schistosome Biological Supply Program (SBSP) at Theodor Bilharz Research Institute (TBRI). Snails were put in contact with miracidia overnight and then snails of each group were washed thoroughly and maintained in a separate aquarium under laboratory conditions. Water temperature was maintained between 24$26^{\circ} \mathrm{C}$ throughout the period of experiment. Snails were tested weekly for shedding cercariae from 25 day post-exposure by exposing them, individually, to fluorescent light in $2 \mathrm{ml}$ of water for 2 hours at $25^{\circ} \mathrm{C}$. Cercarial suspension of each snail was counted using Bouns' fluid and cercarial production/ infected snail were recorded (Parh and James, 1977).

Hematological analysis: Changes in hemocytes of $B$. alexandrina as to their total and differential hemocytes count (granulocyte and hayalinocyte) were determined in snail samples from parents and their tolerant progenies of $1^{\text {st }}, 2^{\text {nd }} \& 3^{\text {rd }}$ generations. Hemolymph samples were obtained from examined snails by puncturing the previously cleaned shell (with $70 \%$ ethanol) between the first and second inner whorls. The number of hemocytes $/ \mathrm{mm}^{3}$ of hemolymph was counted in a Burker-Turk hemocytometer (Van der Knaap et al, 1981) for total count. Monolayers of hemocytes were prepared and stained with Giemsa's stain for $20 \mathrm{~min}$ according to the method of Abdul-Salam and Michelson (1983). Light microscopy preparation of hemolymph smears were fixed in methanol and stained with Giemsa stain (Cheng and Guida, 1980), then differential hemocytes counts were performed (Brown, 
1980). Data were presented as mean \pm S.E. (M) and $\mathrm{n}$ represented the number of snails used in the experiment. Statistical calculations were based on analysis of variance (ANOVA). Differences were considered significant when $\mathrm{P}<0.05$.

Molecular analysis: Extraction: Snail feet from the five parents snail groups, $1^{\text {st }}, 2^{\text {nd }} \&$ $3^{\text {rd }}$ generations and Lab breeding were dissected free, fixed in $70 \%$ ethanol and maintained at $4^{\circ} \mathrm{C}$ till used. Genomic deoxyribonucleic acid (DNA) was extracted from five snail samples (Junghans et al, 1990). From each sample, $0.1 \mathrm{~g}$ to $0.5 \mathrm{~g}$ of foot snail tissue was ground in a motor and pestle in liquid nitrogen until a fine powder was obtained. After grinding, thawing of ground tissues was prevented and transferred to $1.5 \mathrm{ml}$ Eppendorf tube. Then $700 \mu$ of extraction buffer was added and mixed well. Tubes were incubated at $4^{\circ} \mathrm{C}$ for $10 \mathrm{~min}$ and then centrifuged at 12000 r.p.m for $10 \mathrm{~min}$. The supernatant was transferred to a new sterile Eppendorf tube \& $500 \mu$ of phenol: chloroform: isoamyl at a ratio of $25: 24: 1$ was added to the supernatant and mixed. The tubes were centrifuged at 12000r.p.m for 5min, then the aqueous phase was transferred to a new sterile tube and $750 \mu$ of cold isopropanol were added and mixed then incubated at $4^{\circ} \mathrm{C}$ for $20 \mathrm{~min}$. Then, tubes were centrifuged for five min. to aggregate the DNA pellets then were washed in $70 \%$ ethanol and left to dry for about 30min. The pellets were re-dissolved in $100 \mu \mathrm{TE}$ buffer then RNAase (5units/ $\mu \mathrm{l})$ for each sample $10 \mu 1$ were added to remove RNA from samples and was incubated at $37^{\circ} \mathrm{C}$ for two hours to have pure DNA which was kept in refrigerator till use. DNA concentrations were measured by UV-SpectroPhotometer at a wave length of $260-280 \mathrm{~nm}$. DNA integrity and concentrations were estimated by comparing with molecular weight standard on $0.7 \%$ agarose gel electrophoresis.

PCR: Genomic DNA of different groups was subjected to polymerase chain reaction (PCR) using primers. ISSR-PCR reactions were conducted using randomly selected ten ISSR primers, for the genotypes of snails (Tab. 1). Amplification was carried out in stratgene PCR 96 which was programmed as follows: Denaturation (one cycle) $94^{\circ} \mathrm{C}$ for $2 \mathrm{~min}$; followed by 30 cycles: as follows $94^{\circ} \mathrm{C}$ for 30 second, $44^{\circ} \mathrm{C}$ for 45 second, $72^{\circ} \mathrm{C}$ for $1 \mathrm{~min}$; and finally one cycle extension at $72^{\circ} \mathrm{C}$ for $20 \mathrm{~min}$; and $4^{\circ} \mathrm{C}$ (infinitive). Gel Electrophoresis: $15 \mu \mathrm{l}$ of PCR-product were resolved in $1.5 \%$ GTG agarose gel electrophoresis with 1x TAE running buffer. The run was performed at $80 \mathrm{~V}$ for $180 \mathrm{~min}$, and the gel was stained with ethidium bromide. A marker of $1 \mathrm{~Kb}$ plus DNA ladder $1 \mu \mathrm{g} / \mu \mathrm{l}$ (Invitrogen) with a total of twenty bands ranging from 12000 to $100 \mathrm{bp}$ was used. Bands were detected on UV- Tran illuminator and photographed by gel documentation system UVP2000.

Table 1: ISSR primers names and their sequences.
\begin{tabular}{|l|l|l|l|}
\hline Primer name & Sequence & Primer name & Sequence \\
\hline $197887 \mathrm{~A}$ & $(\mathrm{CA})_{6} \mathrm{AG}$ & HB11 & $(\mathrm{GT})_{6} \mathrm{CC}$ \\
\hline $844 \mathrm{~A}$ & $(\mathrm{CT})_{8} \mathrm{AC}$ & HB12 & $(\mathrm{CAC})_{3} \mathrm{GC}$ \\
\hline 844B & $(\mathrm{CT})_{8} \mathrm{GC}$ & HB13 & $(\mathrm{GAG})_{3} \mathrm{GC}$ \\
\hline HB8 & $(\mathrm{GA})_{6} \mathrm{GG}$ & HB14 & $(\mathrm{CTC})_{3} \mathrm{GC}$ \\
\hline HB10 & $(\mathrm{GA})_{6} \mathrm{CC}$ & HB15 & $(\mathrm{GTG})_{3} \mathrm{GC}$ \\
\hline
\end{tabular}

\section{Results}

Toxicity to cadmium $(\mathrm{Cd})$ against parent $B$. alexandrina and their progenies: Toxicity of $\mathrm{Cd}$ was examined in adult $B$. alexandrina snails as parents and their selected Cd tolerant progenies through three generations. The presented results showed values of $\mathrm{LC}_{50}$ \& $\mathrm{LC}_{90}, 95 \%$ confidence lower and upper lim- its and slopes of mortality regression lines obtained by probit analysis using SPSS program. It has been shown that there is a gradual increase from survivor tolerant $\mathrm{Cd}$ parents to the selected tolerant progenies till the third generation, $\mathrm{LC}_{50}$ of parents was 2.452 ppm increased to 4.861, 8.466 and $11.5 \mathrm{ppm}$ in the first, second and third generations, 
respectively. Consequently, $\mathrm{LC}_{90}$ of parents was 4.2 , increased to $8.4,16.2 \& 17.5 \mathrm{ppm}$ in the three successive generations, respectively. On the other hand, $\mathrm{LC}_{50} \& \mathrm{LC}_{90}$ values of control snails of the first, second and third generations were fluctuated in narrow range $\left(\mathrm{LC}_{50}\right.$ ranged from 2.548 to $4.6 \&$ $\mathrm{LC}_{90}$ ranged from 4.667 to $8.2 \mathrm{ppm}$ ) suggesting that control snails showed approximately the same $\mathrm{Cd}$ tolerance in the three experiments.

Hematological analysis: Two types of blood cells were distinguished under light mic-roscopy; granulocyte and hayalinocyte. Granulocytes are granular (spreading) hemocytes, measuring $20-25 \mu \mathrm{m}$ in diameter, had plentiful cytoplasm with numerous pseudopodia, irregular nucleus and adhere to glass. Hayalinocyte was morphologically round cell with lower nuclear-cytoplasmic ratio, measuring $12-15 \mu \mathrm{m}$ in diameter and markedly basophilic cytoplasm with abundant dense granules. Comparing the total cells count of parent, $1^{\text {st }}, 2^{\text {nd }} \& 3^{\text {rd }}$ snail generation groups after exposing to $\mathrm{Cd}$, showed a high significant increase in the $3^{\text {rd }}$ generation than the parent one with significant alteration in differential count from parent snails started from $1^{\text {st }}$ generation through the three generations. Details were given in tables $(1 \& 2)$ and figures $(1,2,3 \& 4)$.

Table 2: Probit analysis of mortality of parent field B. alexandrina, their selected Cd tolerant progenies through three generations and corresponding field controls in ppm).

\begin{tabular}{|c|c|c|c|c|c|c|c|c|c|c|}
\hline \multirow[b]{2}{*}{ Snail groups } & \multicolumn{5}{|l|}{ Tested } & \multicolumn{5}{|c|}{ Controls } \\
\hline & $\begin{array}{l}\mathrm{LC}_{50} \\
(\mathrm{ppm})\end{array}$ & $\begin{array}{l}\text { upper } \\
\text { limit }\end{array}$ & $\begin{array}{l}\text { lower limit } \\
\text { (ppm) }\end{array}$ & $\begin{array}{l}\mathrm{LC}_{90} \\
(\mathrm{ppm})\end{array}$ & Slope & $\begin{array}{l}\mathrm{LC}_{50} \\
(\mathrm{ppm})\end{array}$ & $\begin{array}{l}\text { upper } \\
\text { limit }\end{array}$ & $\begin{array}{l}\text { lower } \\
\text { limit }\end{array}$ & $\begin{array}{l}\mathrm{LC}_{90} \\
(\mathrm{ppm})\end{array}$ & Slope \\
\hline Parents & 2.452 & 3.26 & 1.9 & 4.2 & 1.7 & & & & & \\
\hline $1^{\text {st }}$ generation & 4.861 & 5.55 & 4.17 & 8.4 & 1.5 & 4.132 & 5.33 & 3 & 6.2 & 1.39 \\
\hline $2^{\text {nd }}$ generation & 8.466 & 10.88 & 6.5 & 16.2 & 1.67 & 4.6 & 5.99 & 3.5 & 8.2 & 1.69 \\
\hline $3^{\text {rd }}$ generation & 11.5 & 14.26 & 9.27 & 17.5 & 1.54 & 2.548 & 3.625 & 1.72 & 4.667 & 1.84 \\
\hline
\end{tabular}

Table 3: Comparison of hematologic parameters in parents and their progenies through successive generations, G1: $1^{\text {st }}$ generation, G2: $2^{\text {nd }}$ generation and G3: $3^{\text {rd }}$ generation.

\begin{tabular}{|l|cc|c|c|c|}
\hline Types of cells M \pm SD & \multicolumn{2}{|c|}{ Parents } & G1 & G2 & G3 \\
\hline Total cells count & \multicolumn{2}{|c|}{$1250 \pm 141.4$} & $1550 \pm 282.8$ & $2300 \pm 1060.6$ & $2375^{* *} \pm 106.1$ \\
\hline Granulocytes & 57.5 & \pm 0.71 & $79 * * \pm 0$ & $68.5^{* *} \pm 0.71$ & $64.5^{* *} \pm 0.7$ \\
\hline Hyalinocytes & 42.5 & \pm 0.71 & $21 * * * \pm 0$ & $31.5 * * \pm 0.71$ & $35.5^{* *} \pm 0.7$ \\
\hline
\end{tabular}

*significance between parent and each generation $1^{\text {st }}, 2^{\text {nd }} \& 3^{\text {rd }}$ (*significant, $* *$ high significant $* * *$ more highly significant)

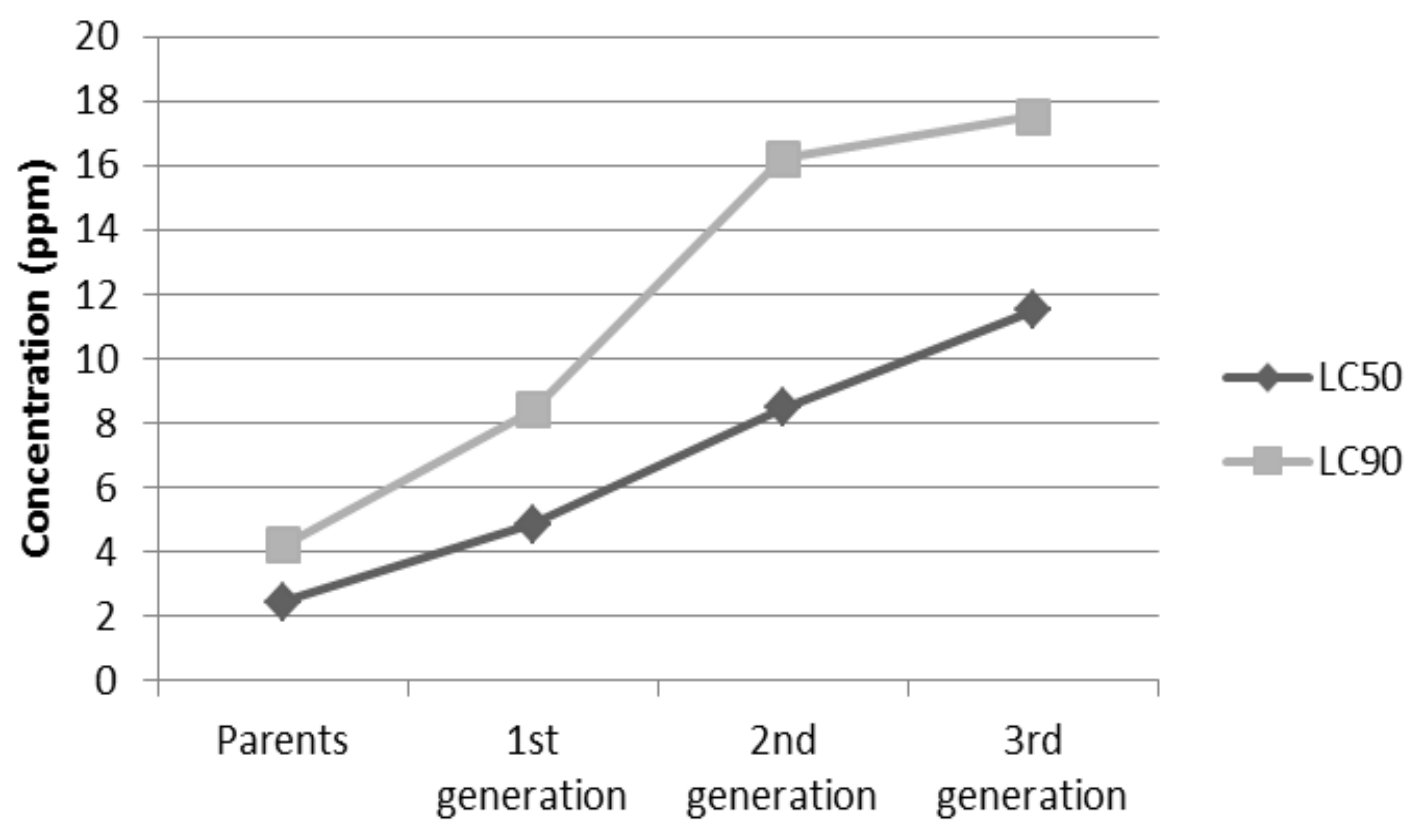

Fig. 1: Toxicity of Cd against $B$. alexandrina snails and selected progenies after $24 \mathrm{~h}$ exposure $\mathrm{LC}_{50}$ and $\mathrm{LC}_{90}$ lethal concentrations. 


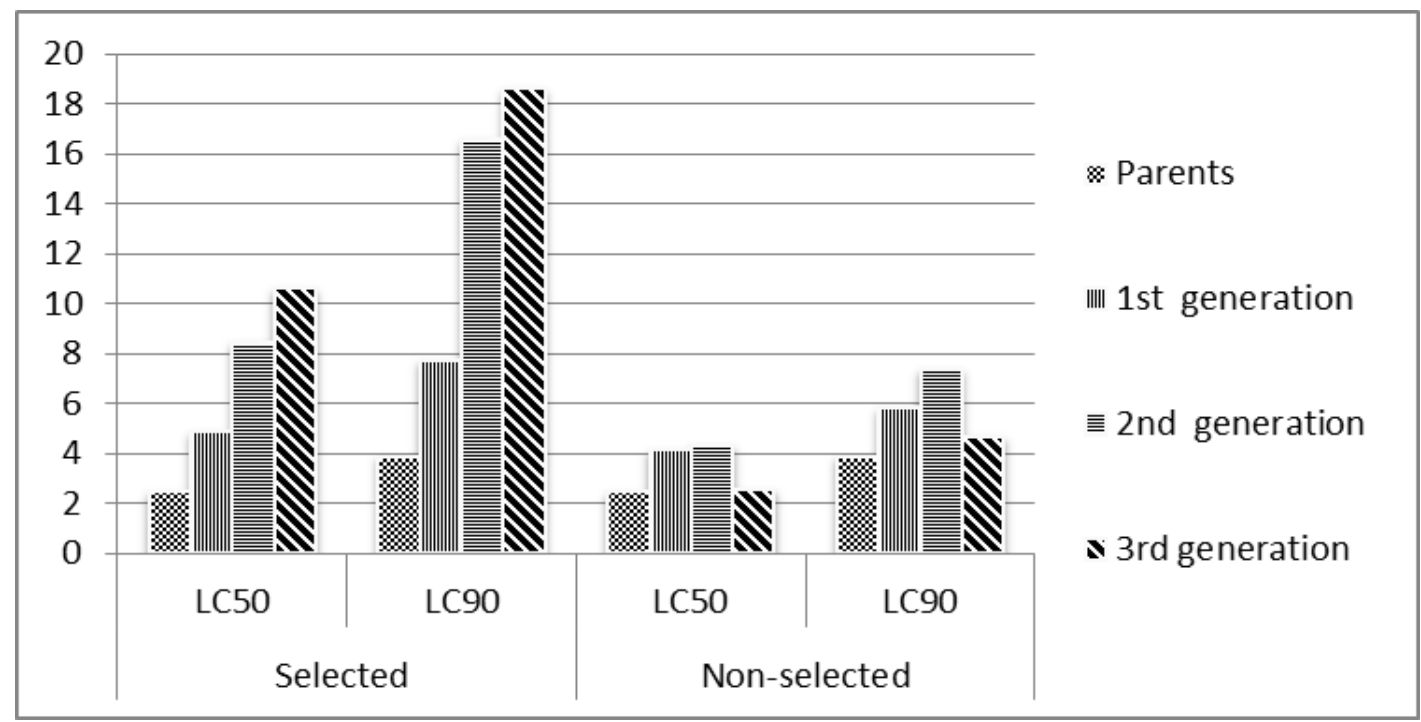

Fig. 2: Comparison of $\mathrm{LC}_{50} \& \mathrm{LC}_{90}$ between parents' B. alexandrina and selected progenies and field B. alexandrina as a control when exposed to $\mathrm{Cd}$.

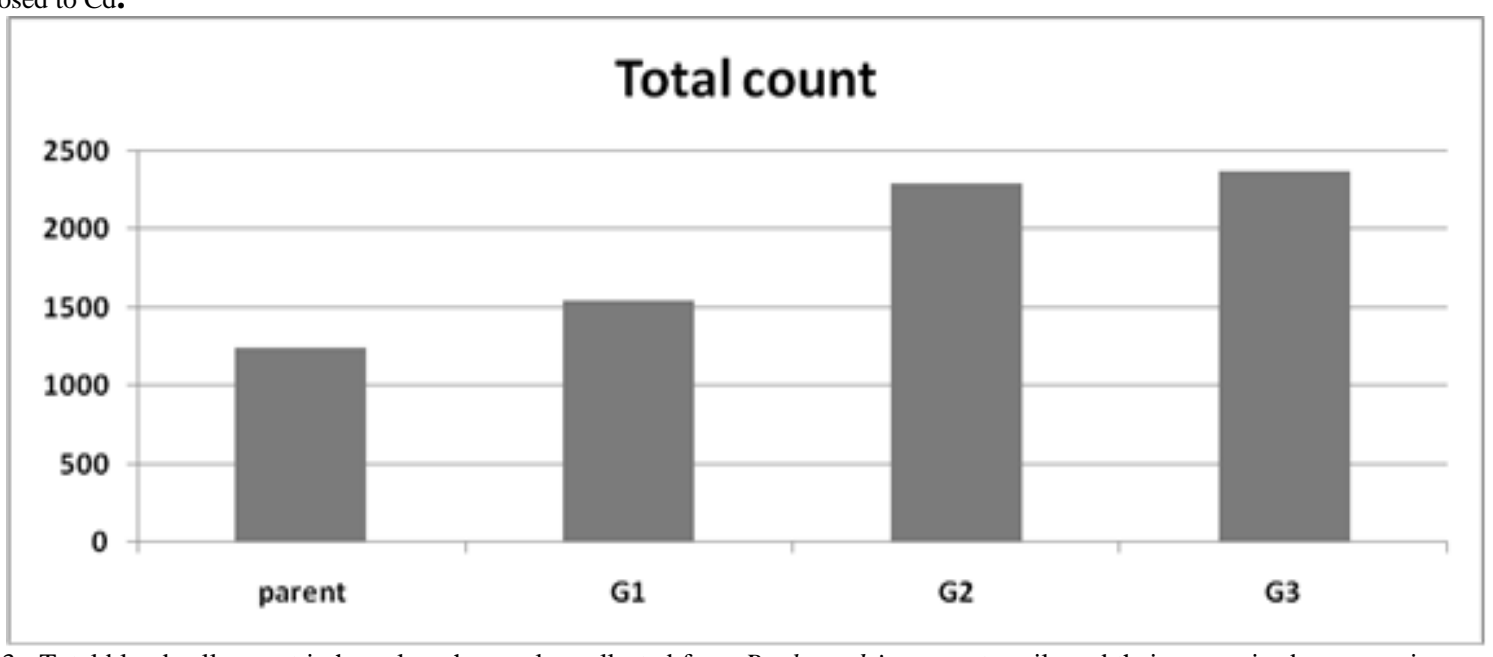

Fig 3: Total blood cells count in hemolymph samples collected from B. alexandrina parent snails and their progenies by successive generations, G1: First generation, G2: Second generation and G3: Third generation.

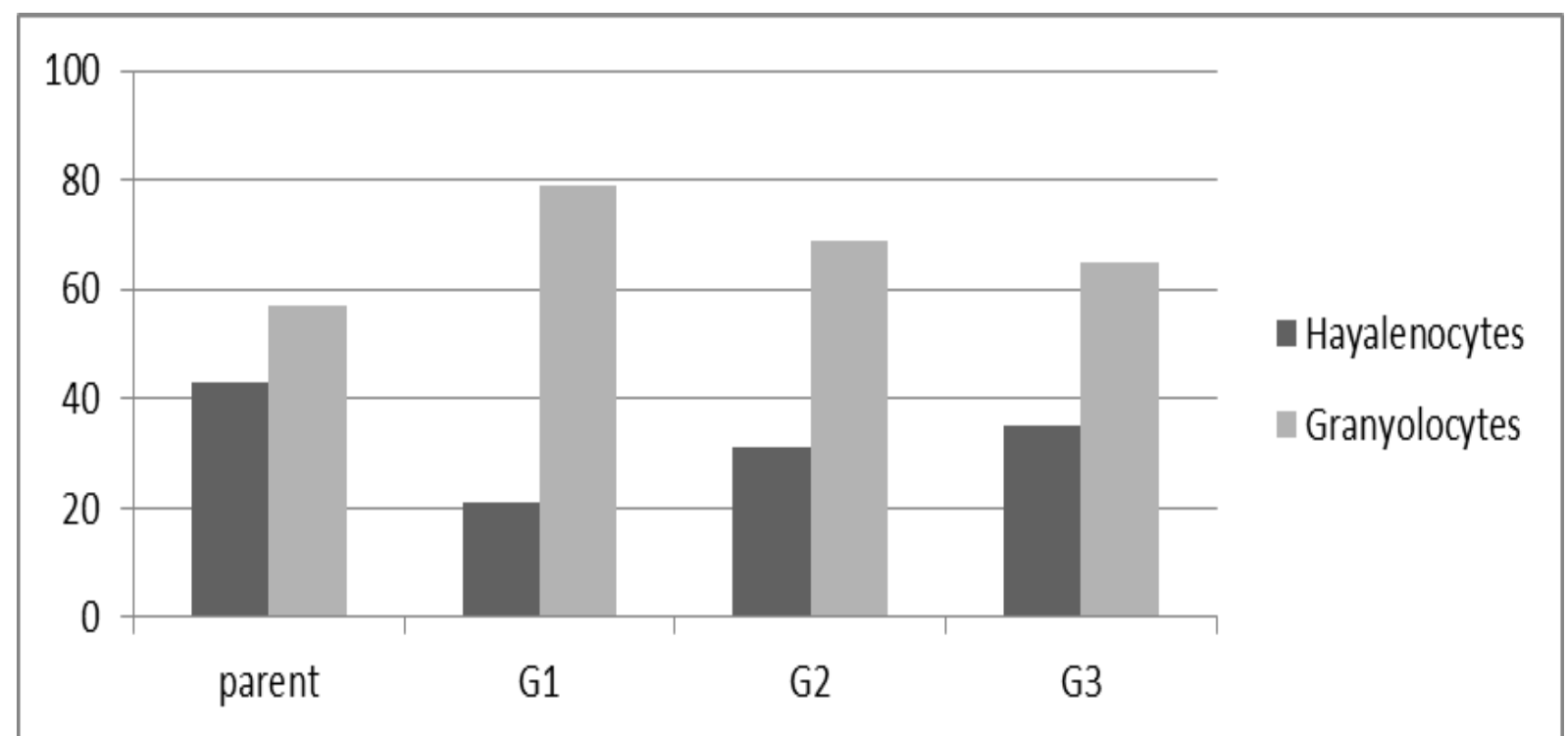

Fig 4: Differential blood cell count in hemolymph samples collected from in B. alexandrina parent snails and progenies by successive generations, G1: First generation, G2: Second generation and G3: Third generation. 
Susceptibility to S. mansoni showed approximately moderate susceptibility of $33.3 \%$ infection, pre-patent period of 26 days, number of cercariae/snail of 1790 \&survival rate of $15 \%$ while selected snails showed resistance to infection, higher pre-patent period over 72 days and higher survival rate of $35 \%$ (Fig. 5).

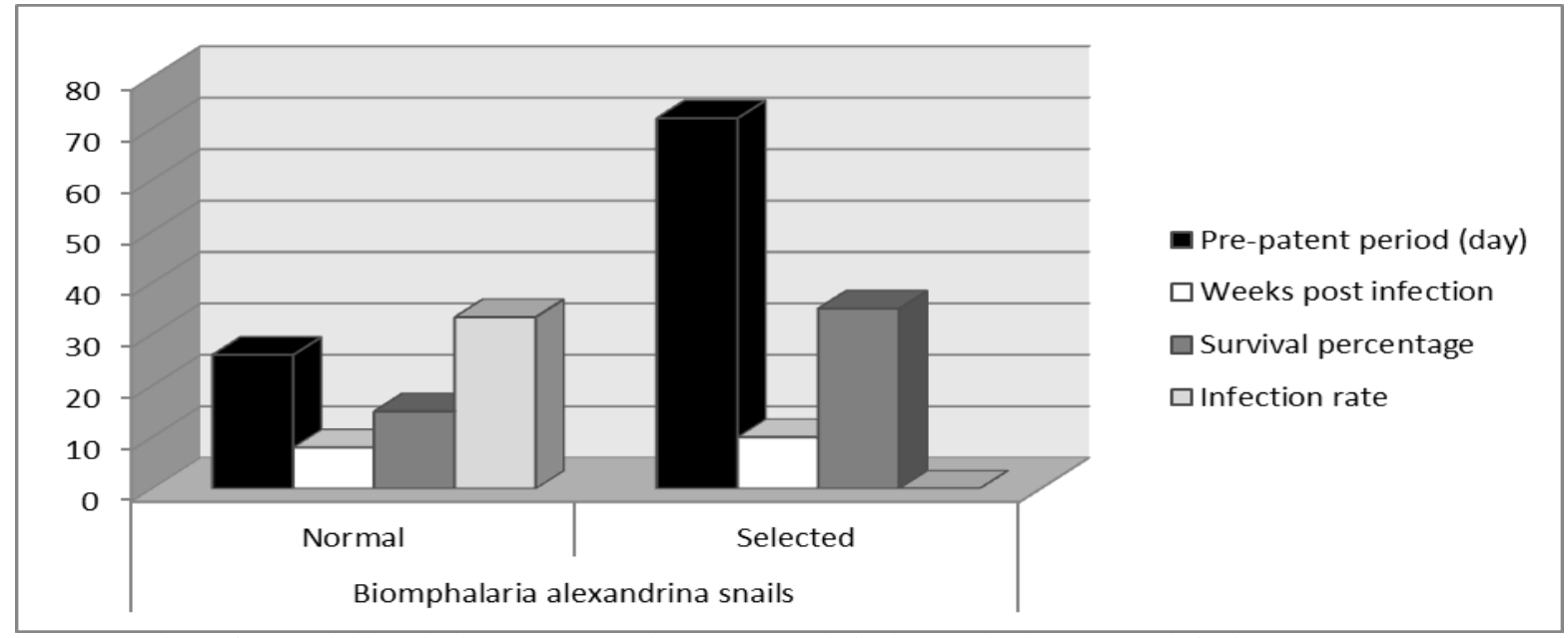

Fig 5: Comparison of susceptibility criteria, pre-patent period, weeks post infection, survival percentage, infection percentage and total number of cercariae/snail between third generation selected for Cd tolerance and laboratory non-selected B. alexandrina snails.

ISSR markers in assessing genetic variation: Genetic diversity among parent $B$. alexandrina, selected progenies for $\mathrm{Cd}$ tolerance till the third generations and laboratory reared non-selected snails, were investigated by ISSR-PCR technique using ten primers. A total of 88 amplification fragments, ranging from 205 to $2065 \mathrm{bp}$ in size were detected, the highest total number of bands (12) was obtained using primers HB08 \& HB14, but, lowest number of bands (5) was by using primer HB12 (Tabs, 4, 5 \& 6, Fig. 6).

By using all primers and according to the total number of amplified bands in each group, the unselected groups, parents and Laboratory showed the highest number of bands (68 \& 67, respectively), while the selected groups under pressure of selection showed less bands $63,65 \& 57$ in G1, G2, \& G3, respectively. Genetic analysis showed that the $3^{\text {rd }}$ generation group was the most unique by total 25 polymorphic bands in all primers, 16 absence $\& 9$ excess. It was characterized by absence of 2 bands of $705 \&$ 610bp using the primer 197887A, absence of 2 bands of $980 \& 600 \mathrm{bp}$ and presence of 2 bands of $915 \&$ AF06 using the primer 844A. Absence of 4 bands of $970,820,735 \&$
$610 \mathrm{bp}$ and the presence of 3 bands of 705 , $670 \& 31 \mathrm{bp}$ using the primer $844 \mathrm{~B}$, the absence of 3 bands of $680,605 \& 365 \mathrm{bp}$ and presence of 2 bands of 735 and $665 \mathrm{bp}$ using the primer HB08. The absence of one band of $540 \mathrm{bp}$ and the presence in one band at 670 using the primer HB12; the absence of one band of 520 using the primer HB13, absence of 2 bands of $755 \& 420 \mathrm{bp}$ and presence of 1 band of 705bp using primer HB14 and at last, the absence of one band of at $890 \mathrm{bp}$ using the primer HB15. Also, $1^{\text {st }}$ generation snail was characterized by 3 polymorphic bands; 2 were absent of 730 \& $615 \mathrm{bp}$ and one excess of 520bp using primer HB11. Also, the $2^{\text {nd }}$ generation snails were characterized by 2 polymorphic bands; one was excess of 640bp using primer 197887A and one was absent of $820 \mathrm{bp}$ using primer HB13. Parent group showed characterization on the presence of 3 excess polymorphic bands of 1385, 290 and $840 \mathrm{bp}$ by using primers 197887A, HB08 \& HB10, respectively. The least characterized snail group was laboratory reared onesthat showed only one excess polymorphic band than the others in all primers and the absence of one band of 505 bp by using the primer HB15. 
Table 5: Total number of amplicons and level of polymorphism among parent $B$. alexandrina, their selected progenies for Cd tolerance and laboratory breading non-selected snail samples as revealed by ISSRs.

\begin{tabular}{|c|c|c|c|}
\hline Primers & Total number of amplified bands & Polymorphic amplified bands & Percentage of Polymorphism \\
\hline 197887A & 10 & 9 & 60 \\
\hline 844A & 6 & 4 & 64 \\
\hline 844B & 11 & 7 & 67 \\
\hline HB08 & 12 & 8 & 50 \\
\hline HB10 & 6 & 3 & 46 \\
\hline HB11 & 11 & 5 & 60 \\
\hline HB12 & 5 & 2 & 61 \\
\hline HB13 & 8 & 5 & 50 \\
\hline HB14 & 12 & 6 & 29 \\
\hline HB15 & 7 & 2 & 58 \\
\hline Total & 88 & 51 & \\
\hline
\end{tabular}

Table 6: Total number of amplified bands in each snail group; parent B. alexandrina, their selected progenies $\mathrm{G} 1: 1^{\text {st }}$ generation, G2: $2^{\text {nd }}$ generation and G3: $3^{\text {rd }}$ generation for Cd tolerance and laboratory breading non-selected (Lab) by using ten ISSR primers.

\begin{tabular}{|c|c|c|c|c|c|}
\hline Primers & Parent & G1 & G2 & G3 & Lab \\
\hline 197887A & 6 & 6 & 7 & 3 & 7 \\
\hline $844 \mathrm{~A}$ & 4 & 4 & 4 & 4 & 4 \\
\hline $844 \mathrm{~B}$ & 8 & 8 & 8 & 7 & 8 \\
\hline HB08 & 9 & 7 & 7 & 7 & 9 \\
\hline HB10 & 6 & 3 & 5 & 3 & 4 \\
\hline HB11 & 9 & 8 & 9 & 9 & 4 \\
\hline HB12 & 4 & 4 & 4 & 4 & 5 \\
\hline HB14 & 7 & 7 & 6 & 5 & 6 \\
\hline HB15 & 8 & 9 & 8 & 9 & 6 \\
\hline Total & 7 & 7 & 7 & 6 & 67 \\
\hline
\end{tabular}

Similarity coefficients estimated among all snails groups ranged from 0. 65-0.94. The highest value $(0.94)$ was between $1^{\text {st }} \& 2^{\text {nd }}$ generations snails, lowest (0.6) was detected between $2^{\text {nd }}$ generation snail group and $3^{\text {rd }}$ generation group (Tab. 7). UPGMA dendrogram (Fig. 7) showed four main clusters, selected G1\& G2 clustered with each other forming first cluster in turn cluster with Lab forming a second one which further cluster with parent forming the third one, that finally cluster with the most divert G3. So, closest relationship was between selected G1\& G2, while Lab and parent snail groups showed median distance between all groups and selected G3 was the most divert.

Table 7: Proximity, similarity, matrices among parent B. alexandrina, selected progenies for Cd tolerance, G1: $1^{\text {st }}$ generation, G2: $2^{\text {nd }}$ generation and G3: $3^{\text {rd }}$ generation and laboratory breading non-selected (Lab) based on ISSR fragment analysis.

\begin{tabular}{|l|c|c|c|c|c|}
\hline \multirow{2}{*}{ Case } & \multicolumn{5}{|c|}{ Matrix File Input } \\
\cline { 2 - 6 } & VAR00001:(parent) & VAR00002 G1 & VAR00003G2 & VAR00004:G3 & VAR00005:Lab \\
\hline VAR00001 & 1.00 & & & & \\
\hline VAR00002 & 0.88 & 1.00 & & & \\
\hline VAR00003 & 0.91 & 0.94 & 1.00 & & \\
\hline VAR00004 & 0.70 & 0.66 & 0.65 & 1.00 & \\
\hline VAR00005 & 0.87 & 0.90 & 0.90 & 0.74 & 1.00 \\
\hline
\end{tabular}

\section{F. 7 \\ Rescaled Distance Cluster Combine}

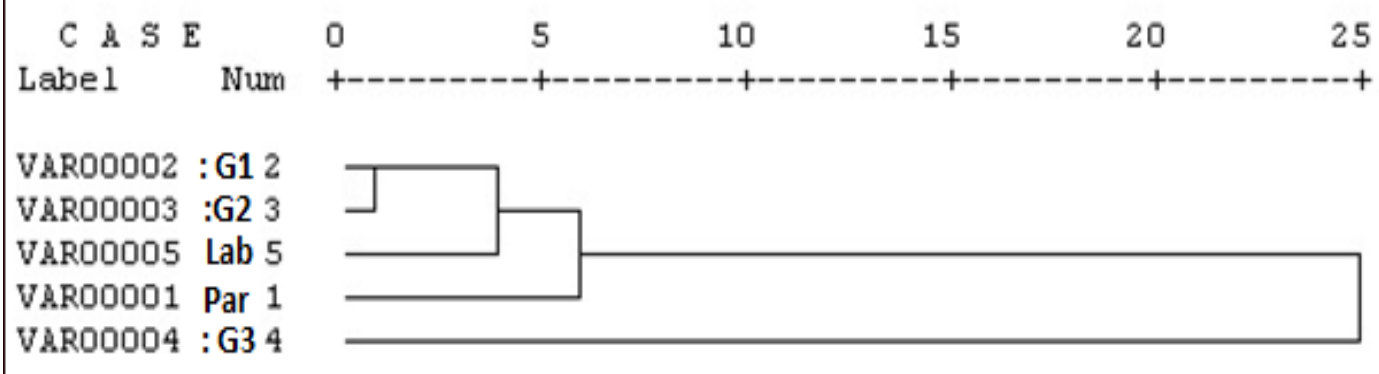

Fig. 7: Dendrogram of diversity and relationships among snail groups; parent B. alexandrina (Par), their selected progenies for Cd tolerance, G1: $1^{\text {st }}$ generation, G2: $2^{\text {nd }}$ generation and G3: $3^{\text {rd }}$ generation and laboratory breading non-selected (Lab) based on ISSRs fragments. 


\section{Discussion}

Environmental parameters influence the organism, producing a non-pathological phenotype, appropriate for that environment causing intraspecific phenotypic variation (Schluter, 2000). Thus, a particular environment can elicit different phenotypes from the same genotype and the ability of organisms to produce different phenotypes under different environmental parameters in natural populations is a critical issue to understand how species might face future changes (Gilbert, 2001). Also, the present work the proposed mating system of selffertilization and selection for Cd toxicity tolerance in field parent Biomphalaria alexandrina snails and their progenies through three generations succeeded to produce snail isolate of higher tolerance than their parents, more than four times. B. alexandrina snails showed gradual increase in $\mathrm{Cd}$ tolerance through the successive generations produced by self-fertilization. $\mathrm{LC}_{50}$ increased from $2.45 \mathrm{ppm}$ in parents to $4.86,8.46 \& 11.5 \mathrm{ppm}$ in $1^{\text {st }} 2^{\text {nd }} \& 3^{\text {rd }}$ generations (G1, G2 \& G3), respectively. This result is agreed with ElKhayat and Gawish (2006), on studying the sensitivity of $B$. alexandrina to water extract of the plant molluscicide Anagallis arvensis through five generations produced by selffertilization of the most tolerant snails. The authors showed gradual increase in $\mathrm{LC}_{50}$ and $\mathrm{LC}_{90}$ values started from the $3^{\text {rd }}$ generation till the $5^{\text {th }}$ generation.

The present results of the total cells count of the selected G1, G2 \& G3 snail generation groups after exposing to $\mathrm{Cd}$, it was resulted in high significant increase in the third generation group their parents. This alteration in the hematological content of the selected snails especially in the third generation may be considered as a physiological characteristic that developed under the pressure of selection for Cd tolerance causing stronger immune defense mechanism. Also, in the earlier studies of different snail species, total hemocyte count has been reported to increase by heavy metal pollution (Pipe et al,
1995; 1999; Fisher et al, 2000) and a significant increase in the percentage of granulocytes (Pickwell and Steinert, 1984). In a trial to cleare how the snail immune-biology is related to the hematological criteria, Malek and Cheng (1974) explained that circulating hemocytes react against foreign bodies, digest and transport nutrients, accumulate various toxic substances, such as heavy metals, pesticides and molluscicides. Helal et al. (2003) observed significant increases in $B$. alexandrina hemocytes after exposure to the water extract of the plant Euphorbia peplus, after the second week, and after exposure to Praziquantel after $3^{\text {rd }}$ and $4^{\text {th }}$ weeks. They showed behavioral and structural changes in hemocytes, aggregation in clusters, after long exposure to the tested molluscicides. The present study recorded change in susceptibility to $S$. mansoni infection in selected Cd tolerant $B$. alexandrina (G3) from moderatory susceptible as in non-selected ones to refractory tendency suggesting trait association between $\mathrm{Cd}$ tolerance and refractory tendenncy. Also, a probable explanation for the decrease in susceptibility that the selection for $\mathrm{Cd}$ tolerance evolved snail immunue response; proved by significant alteration in hematological creiteria; to react against forien bodies of the schistosome sporocysts as well as to react against $\mathrm{Cd}$ toxicity. Also, Pan (1963), Sullivan and Richards (1981) and Loker et al. (1982) proved that hemocytes (phagocytic immune cells) of B. glabrata, genetically-selected for susceptibility or resistance to infection by larval S. mansoni, have been shown to react differentially to invading miracidia. Circulating hemocytes of susceptible strains do not recognize and kill invading larvae, whereas in resistant snails developing larvae are rapidly encapsulated by hemocytes and killed within 24-48 hours of infection. Also, Zahoor et al. (2010) and Negrão-Corrêa et al. (2007) suggested that the internal defense system (IDS) is one of the factors that influence the susceptibility pattern of snails. This system was stimulated by the excretory/ se- 
cretory products of the penetrating miracidia. Its main action is mediated by the phagocytic hemocytes in cooperation with humoral components. In addition, this change could be explained by conclusion of ElKhayat et al. (2008) that there was more expectation of genetic alterations or mutation to occur in snails which practice selffertilization and snail susceptibility will be affected only if genetic segregation or isolation developed under the effect of mating system leads to certain snail lines which differ in their susceptibly. The abundance of recent advance techniques for screening polymorphic markers has allowed the extension of genetic analysis of Biomphalaria snail in aspects regarding identification, susceptibility to schistosome infection and tolerance to molluscicides and environmental pollutants. Mohamed et al. (2011) used PCR-RAPD technique to identify various $B$. alexandrina strains collected from five Egyptian governorates. Also, El-Khayat et al. (2015) used ISSR-PCR technique for studying genetic variations of Lymnaea natalensis collected from four Egyptian Governorates and compared it with laboratory snails. The ISSRPCR genetic analysis used in the present study among two non-selected snail groups, parent field and Lab B. alexandrina and three selected groups for Cd tolerance; $1^{\text {st }}$, $2^{\text {nd }}$ and $3^{\text {rd }}$ generations revealed that $3^{\text {rd }}$ generation snail group was the most unique by total 25 polymorphic bands produced by ten primers, 16 absence and 9 excess. The similarity coefficient between the five examined groups based on ISSR fragment analysis ranged from 0.65 to 0.94 . The highest value was between $1^{\text {st }}$ and $2^{\text {nd }}$ generations and the lowest value was between $2^{\text {nd }}$ and $3^{\text {rd }}$ generation. In addition, the dendograme based on ISSR fragment analysis showed that $3^{\text {rd }}$ generation is the farthest apart other snail groups. This means that $3^{\text {rd }}$ generation of $\mathrm{Cd}$ tolerant snails could be genetically changed and became different from other snail groups under pressure of selection for Cd toxicity tolerance.

\section{Conclusion}

The outcome results showed that certain $B$. alexandrina snails can tolerate $\mathrm{Cd}$ toxicity and this tolerance could be extended and upgraded by selection and self-fertilization mating system to produce genetically different generations for their $\mathrm{Cd}$ toxicity tolerance, hematological creiteria and susceptibility to $S$. mansoni infection.

\section{References}

Abbott, WS, 1925: A method of computing the effectiveness of an insecticide. J. Econ. Entomol, 18, 2:265-7.

Abdul-Salam, JM, Michelson, EH, 1983: Schistosoma mansoni: immunofluorescent detection of its antigen reacting with Biomphalaria glabrata amoebocytes. Exp. Parasitol. 55, 1:132-7.

Abd Allah, AT, Wanas, MQS, Thompson, SN, 1997: Effects of heavy metals on survival and growth of Biomphalaria glabrata say (Gastropoda: Pulmonata) and interaction with schistosome infection. J. Moll. Stud. 63:79-86.

Barbosa, FS, Coimbra, JR, 1979: C.E.A. Esquistossomosemansônica autóctone no Distrito Federal. Brasil. Rev. Saúdepúbl., S. Paulo, 13: 108-12.

Brown, BE, 1978: Lead detoxiccation by a coppertolerant isopod. Nature, London, 276:388-90. Brown, BA, 1980: Hematology Principles and Procedures, In: $3^{\text {rd }}$ ed. Lea and Febiger, Philadelphia, PA.

Bryan, GW, Gibbs, PE, 1983: Heavy metals in the Fal Estuary, Cornwall: a study of long term contamination by mining waste and its effects on estuarine organisms: Marine Biological Association of the United Kingdom. Occasional Publication Series, no.2.

Charbonnel, N, Angers, B, Debain, C, Razatavonjizay, $\mathrm{R}$, Bremond, $\mathrm{P}$, et al, 2002: The influence of mating system, demography, parasites and colonization on the genetic structure of Biomphalaria pfeifferi in Madagascar. Mol. Ecol. 11, 11:2213-28

Cheng, T.C, Guida, V.G. (1980): Hemocy-tes of Bulinus truncates rohlfsi (Mollusca: Gastropoda). J. Invert. Pathol. 35, 2:158-67.

Depledge MH, Rainbow PS, 1990: Models of regulation and accumulation of trace metals in marine invertebrates. Comp. Biochem. Physiol. 97, C:1-7.

El-Khayat, HMM, Gawish, FA, 2006: Laboratory induced resistance to Anagallis arvensis as 
a plant molluscicide in Biomphalaria alexandrina snails, Egypt. J. Nat. Toxin 3:97-117.

El-Khayat, HMM, Mahmoud, KMA, Ab-delHamid, H, Abu El Einin, HM, 2015: Applications of ISSR rDNA in detecting genetic variations in Lymnaea natalensis snails with focusing on the characterization of their collecting sites in certain Egyptian Governorates. Afri. J. Biotechnol. 14, 16:1354-63.

El-Khayat, HMM, Abu El Einin, HM, Gawish, FA, 2008: Determination of allozyme, protein and schistosome susceptibility in Biomphalaria alexandrina progenies produced by self and cross fertilization. J. Egypt. Soc. Parasitol. 38, 3:1007-24.

El-Khayat, HMM, Tawfik, AA, Abo ElHassan, AA, Saber, MA, 2007: Variation in genetic structure and susceptibility to Schistosoma mansoni infection among fourteen populations of Biomphalaria alexandrina. J. Schisto. Infect. End. Dis. 29:31-52.

El-Khayat, HMM, Saber, MA, Abu ElHassan, A, 2005: Study on the susceptibility of Biomphalaria alexandrina collected from five different localities in Egypt to infection with local strain of Schistosoma mansoni. Egypt. J. Schisto. Infect. End. Dis. 27:39-50.

Fisher, WS, Oliver, LM, Winstead, JT, Long, ER, 2000: A survey of oysters Crass-ostrea virginica from Tampa Bay, Florida: associations of internal defense measurements with contaminant burdens. Aquat. Toxicol. 51:115-38.

Ghariani, S, Trifi-Farah, N, Chakroun, M, Marghali, S, 2003: Genetic diversity in Tunisian perennial ryegrass revealed by ISSR markers. Genet. Resour. Crop Evol. 50:809-15.

Gilbert, SF, 2001: Ecological developmen-tal biology: developmental biology meets the real world. Dev. Biol. 233:1-12.

Helal, IB, El-Mehlawy, MH, Rizk, ET, El-Khodary, GM, 2003: Effect of Euphorbi a peplus plant extract and the antihelmenthic prazequantel on the defenc e system of Biomphalaria alexandria snail. Egypt. J. Aquat. Biol. Fish 7: 501-5.

Fisher, WS, Oliver, LM, Winstead, JT, Long, ER, 2000: A survey of oysters Crass-ostrea virginica from Tampa Bay, Florida: associations of internal defense measurements with contaminant burdens. Aquat. Toxicol. 51:115-38.

Jarne, P, Theron, A, 2001: Genetic structure in natural populations of flukes and snails: a practi- cal approach and review. Parasitology 123: S2740.

Jelnes, JE, 1987: Laboratory selection for increased tolerance to niclosamide in Bulinus truncates (Gastropoda: Planorbidae). Anna. Trop. Med. Parasitol. 81, 2:125-7.

Junghans, H, Metzlaff, M, 1990: A simple and rapid method for the preparation of total plant DNA. Biotech. 8, 2:176-9.

Kambale, NA, Potdar, VV, 2010: Hematological analysis of Molluscan species Bellamya bengalensis and Lamiellidens marginalis Biological Forum. An Int. J. 2, 1: 70-2.

Lam, PKS, 1996: Inter-population differences in acute response of Brotia hainanensis (Gastropoda: Prosobranchia) to cadmium: genetic or environmental variance. Environ. Poll. 94:1-7.

Lie, K, 1982: Survival of Schistosoma mansoni and other trematode larvae in the snail Biomphalaria glabrata.A discussion of the interference theory. Trop. Geog. Med. 34: 111-22.

Loker, ES, Bayne, CJ, 1986: Immunity to trematode larvae in the snail Biomphalaria. Symp. Zool. Soc. Land. 56:199-220.

Loker, ES, Bayne, CJ, Buckley, PM, Kru-se, KT, 1982: Ultrastructure of encapsulation of Schistosoma mansoni mother sporocysts by hemocytes of juveniles of the 10-R2 strain of Biomphalaria glabrata. J. Parasitol. 68, 1:8494.

Newton, WL, 1963: The development in the laboratory of resistance to sodium pentachlorophenate in Australorbis glabratus. Bull. WHO 29:539-45.

Malek, EA, Cheng, TC, 1974: Medical and Economic MalacologyAcademic Press. New York.

Mohamed, AH, Sharaf El-Din, AT, Mohamed, AM, Habib, R, 2011: Identification of various Biomphalaria alexandrina strains collected from five Egyptian governorates using RAPD and species-specific PCR techniques. Am. J. Mol. Biol. 1:17-25.

Mohamed, AH, Sharaf El-Din, AT, Moham ed, AM, Habib, R, 2012: Relationship between genetic variability and susceptibility of $B i$ omphalaria alexandrina snails to Schistosoma mansoni infection. Mem. Inst. Oswaldo Cruz. 107, 3:326-37.

Moreno, S, Martín, JP, Ortiz, JM, 1998: Intersimple sequence repeats PCR for characterization of closely related grapevine germplasm. Euphytica 101:117-25. 
Negrão-Corrêa, D, Pereira, CAJ, Rosa, F M, Martins-Souza, RL, Andrade, ZA, Co-elho, PMZ, 2007: Molluscan response to parasite, Biomphalaria and Schistosoma mansoni interaction. Inv. Surv. J. 4:101-11.

Oliver, LM, Fisher, WS, 1995: Comparative form and function of oyster Crassostrea virginica hemocytes from Apalachicola Bay, Florida and Chesapeake Bay (Virginia). Dis. Aquat. Organ. 22:217-25.

Oliveira, ALD, Levada, PM, Zanotti-Magalhaes, EM, Magalhães, LA, Ribeiro-Pa-es, JT, 2010: Differences in the number of hemocytes in the snail host Biomphalaria tenagophila, resistant and susceptible to Schistosoma mansoni infection. Genet. Mol. Res. 9, 4:2436-45.

Pan, CT, 1963: Generalized and focal tissue responses in the snail, Australorbis glab-ratus, Infected with Schistosoma mansoni. Ann. N Y Acad. Sci. 113:475-85.

Pickwell, GV, Steinert, SA, 1984: Serum biochemical and cellular responses to experimental cupric ion challenge in mussels. Mar. Environ. Res., 14: 245-67.

Pipe, RK, Coles, JA, Carissan, FMM, Ramanathan, K, 1999: Copper induced immunomodulation in the marine mussel Mytilusedulis. Aquat. Toxicol. 46:43-54.

Pipe, RK, Coles, JA, Thomas, ME, Fossato, V U, Pulsford, AL, 1995: Evidence for environmentally derived immunomodulation in mussels from Venice lagoon. Aquat. Toxicol. 32:59-73.

Prah, SK, James, C, 1977: The influence of physical factors on the survival and infectivity of miracidia of Schistosoma mansoni and Schistosoma haematobium. 1. Effect of temperature and ultra-violet light. J. Helminthol. 51: 73-85

Prugnolle, F, Manica, A, Charpentier, M, Guegan, JF, Guernier, V, et al, 2005: Pathogen-driven selection and worldwide HLA class I diversity. Current Biology, 15, 11:1022-7.

Saber, MA, Abo El-Hassan, AA, El-Khay-at, HMM, 2007: Correlation of isoenzyme patterns and susceptibility of Biomphalaria alexandrina to Schistosoma mansoni infection. J. Schisto. Infect. Endem. Dis. 29:53-65.

Saber, MA, Abo El-Hassan, AA, El-Kha-yat, HMM, 2005: Electrophoretic analysis of acid Phosphatase in Biomphalaria alexandrina and its relation to susceptibility to Schistosoma mansoni infection. Egypt. J. Schisto. Infect. Endem. Dis. 27:51-8.
Schluter, D, 2000: The Ecology of Adaptive Radiation (Oxford Univ. Press, Oxford, UK Standley, C.J, Goodacre, SL, Wade, CM, Stothard, JR, 2014: The population genetic structure of Biomphalaria choanomphala in Lake Victoria, East Africa: implications for schistosomiasis transmission. Parasites Vectors, 7:52430.

Sullivan, JT, Cheng, TC, Chen, CC, 1984: Genetic selection for tolerance to niclosamide and copper in Biomphalara glabrata (Mollusca: Pulmonata). Tropenmed. Parasitol. 35:189-94.

Sullivan, JT, Richards, CS, 1981: Schistosoma mansoni, NIH-SM-PR-2 strain, in susceptible and nonsusceptible stocks of Biomphalaria glabrata: comparative histology. J. Parasitol. 67, 5:702-8.

Szenejko, M, Śmietana, P, Stępień, E, 2016: Genetic diversity of Poapratensis L. depending on geographical origin and compared with genetic markers. Peer J. 4:e2489; Doi 10.7717/ peerj.2489

Tallarico, F, Cantinha, RS, Nakano, E, 2012: Biomphalaria glabrata (Say, 1818): a sui Table organism for ecotoxicological studies. http:// www.icmam.com.br/docs/abstract_model. pdf.

Van Der Knaap, WPW, Sminia, T, Kroese, F GM, Dikkeboom, R, 1981: Elimination of bacteria from the circulation of the pond snail Lymnae astagnalis. Develop. Comp. Immunol. 5, 1:21-32.

Van Der Knaap, WPW, Loker, ES, 1990: Immune mechanisms in trematode-snail interaction. Parasitol. Today 6: 175-82.

Wethington, AR, Lydeard, C, 2007: A molecular phylogeny of Physidae (Gastropoda: Basommatophora) based on mitochondrial DNA sequences. J. Mollus. Stud. 73, 3: 241-57.

Wright, BJ, Bickham-Wright, U, Yoshino, T P, Jackson, MB, 2017: $\mathrm{H}^{+}$channels in embryon ic Biomphalaria glabrata cell membranes: Putative roles in snail host-schistosome interactions. PLOS Neglected Tropical Diseases. https:// doi.org/10.1371/ journal.pntd.0005467.

Yasuraoka, K, Ichii, S, Irie, Y, 1987: Lack of resistance of the snail Oncomelania nosophora after years of exposure to molluscicides. Parasitol. Res. 73, 2:184-5.

Zahoor, Z, Davies, AJ, Kirk, RS, Rollinson, D, Walker, AJ, 2010: Larval excretory-secretory products from the parasite Schistosoma mansoni modulate HSP70 protein expression in de- 
fence cells of its snail host, Biomphalaria glabrata. Cell Stress Chapter 15, 5:639-50.

Zietkiewicz, E, Rafalski, A, Labuda, D, 1994:
Genome fingerprinting by simple sequence repeat (SSR)-anchored polymerase chain reaction amplification. Genomics 20:176-83.

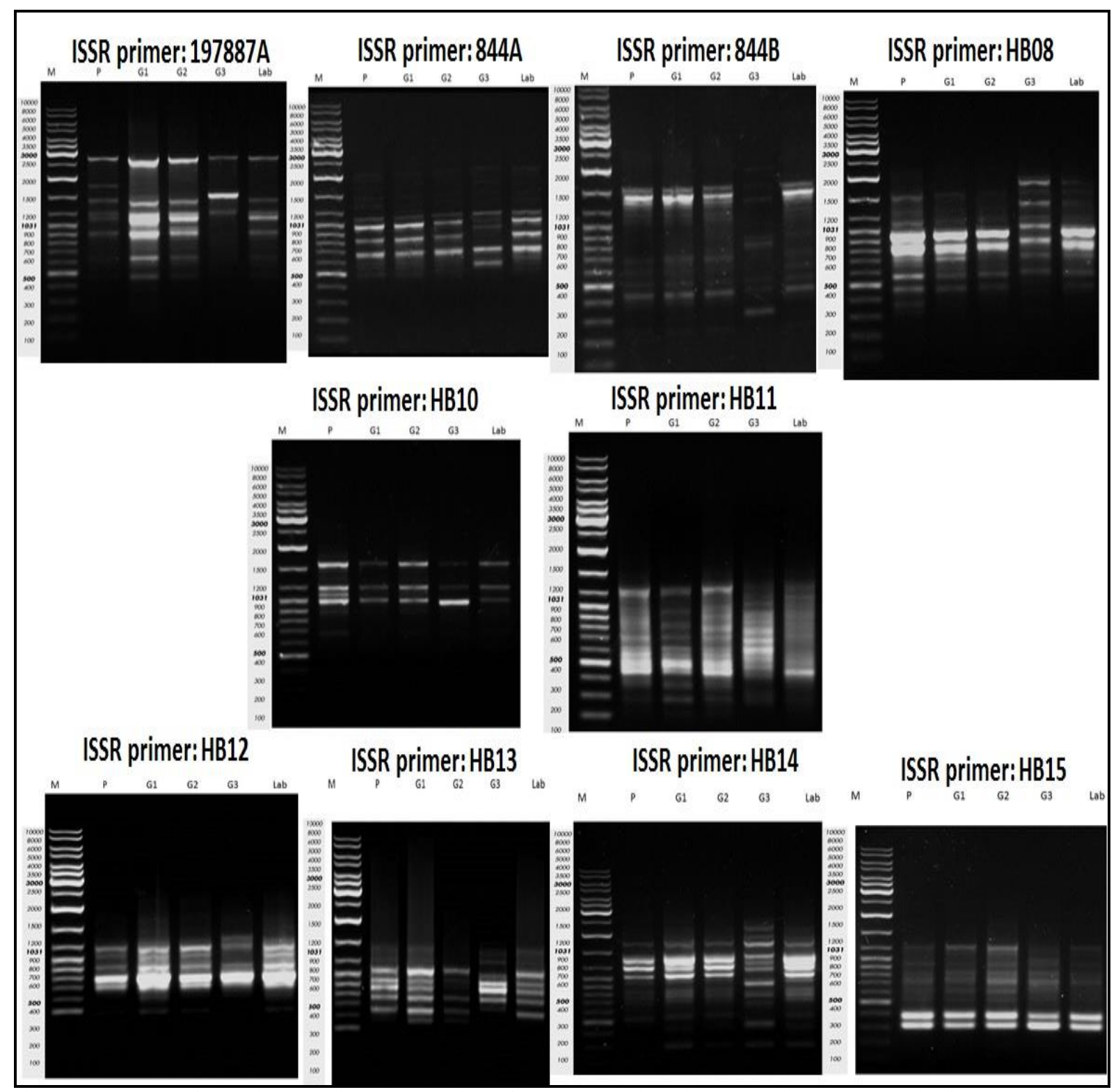

Fig. 6: PCR products of genomic DNA using ten ISSR primers from parent $B$. alexandrina $(\mathrm{P})$; their selected progenies for $\mathrm{Cd}$ tolerance, $\mathrm{G} 1$ : $1^{\text {st }}$ generation, G2: $2^{\text {nd }}$ generation and G3: $3^{\text {rd }}$ generation and laboratory breading non-selected (Lab) snail samples. 
Table 4: DNA polymorphism of 5 snail samples; parent $B$. alexandrina, selected progenies for Cd tolerance, G1: $1^{\text {st }}$ generation, G2: $2^{\text {nd }}$ generation and G3: ${ }^{\text {rd }}$ generation and laboratory breading non-selected (Lab) using ten ISSR primers.

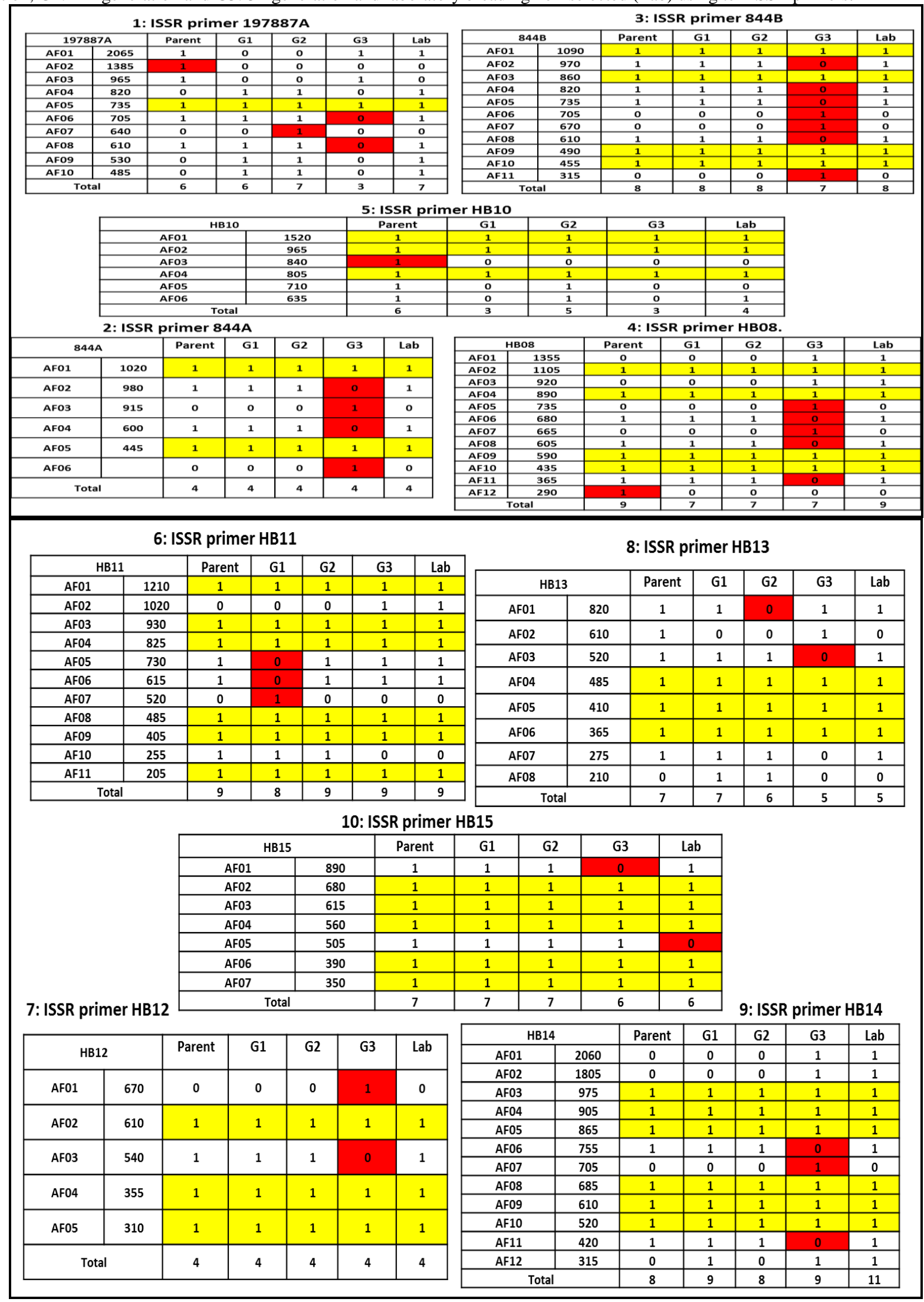

